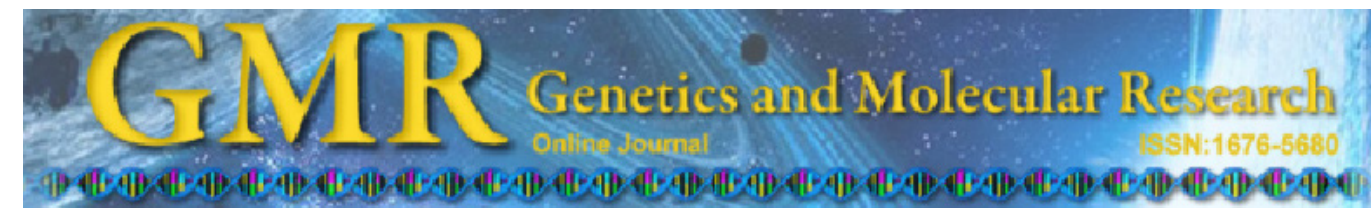

\title{
Genotoxicity in oral epithelial cells in children caused by nickel in metal crowns
}

\author{
J. Morán-Martínez ${ }^{1}$, K.D. Monreal-de Luna ${ }^{1}$, N.D. Betancourt-Martínez ${ }^{1}$, \\ P. Carranza-Rosales ${ }^{2}$, J.G. Contreras-Martínez ${ }^{1}$, M.C. López-Meza ${ }^{3}$ and \\ O. Rodríguez-Villarreal ${ }^{3}$
}

${ }^{1}$ Departamento de Biología Celular y Ultraestructura, Centro de Investigación Biomédica, Facultad de Medicina de Torréon, Universidad Autónoma de Coahuila, Torreón, Coahuila, México

${ }^{2}$ Departmento de Biología Celular y Molecular,

Centro de Investigaciones Biomédicas del Noreste, Instituto Mexicano del Seguro Social, Monterrey, Nuevo León, México ${ }^{3}$ Clínica de Odontología Pediátrica, Facultad de Odontología, Universidad Autónoma de Coahuila, Torreón, Coahuila, México

Corresponding author: J. Morán-Martínez

E-mail: javmoran@yahoo.com

Genet. Mol. Res. 12 (3): 3178-3185 (2013)

Received August 9, 2012

Accepted November 22, 2012

Published August 29, 2013

DOI http://dx.doi.org/10.4238/2013.August.29.1

\begin{abstract}
The micronucleus (MN) assay evaluates the effects of low doses of genotoxic carcinogens and can detect structural lesions that survive mitotic cycles. The objective of this study was to determine both the genotoxicity of nickel (Ni) in buccal epithelial cells and the urinary excretion of $\mathrm{Ni}$ in children with metal crowns. This was a prospective longitudinal study based on 37 patients selected at the Facultad de Odontología de la Universidad Autónoma de Coahuila. MN assays were performed using buccal cells from the 37 patients, and Ni levels were determined from urine samples using inductively coupled plasma mass spectrometry at 1 (basal value), 15, and 45 days following the placement of crowns in each patient. Ni urinary excretion levels increased from 2.12 \pm 1.23 to $3.86 \pm 2.96 \mu \mathrm{g} \mathrm{Ni} / \mathrm{g}$ creatinine $(\mathrm{P}<0.05)$ and the frequency of exposed micronuclei increased from $4.67 \pm 0.15$ to $6.78 \pm 0.167 / 1000$ cells $(\mathrm{P}<0.05)$ between 1 and 45 days post-crown placement. These
\end{abstract}


results suggest that odontological exposure to metal crowns results in genotoxic damage at the cellular level of the oral mucosa and an increase in the urinary excretion of $\mathrm{Ni}$ within 45 days of exposure.

Key words: Micronucleus; Nickel; Genotoxicity; Oral epithelial cells

\section{INTRODUCTION}

In odontology, nickel (Ni) is used for fashion brackets, fillings, space maintainers, and crowns (Bass et al., 1993; Westphalen et al., 2008). The oral cavity is particularly suited for the biodegradation of metals due to its ionic, thermal, microbiological, and enzymatic properties (Vijaya Bhaskar and Subba-Reddy, 1997; Faccioni et al., 2003; Shin and Hwang, 2003; Liu et al., 2007; Amini et al., 2008). Ni can be found in dental alloys in varying amounts and, depending on its function, is differentiated into 3 types: a) Ni-chromium $(\mathrm{Cr})$ alloys for fixed prosthodontics (metal-ceramic composites) in which $\mathrm{Ni}$ is present in high proportions; b) stainless steels for conventional fixed or removable orthodontic apparatuses, which contain very low proportions of $\mathrm{Ni}$; and c) new Ni-titanium alloys for orthodontics, with shape-memory and superelasticity in which Ni is present in intermediate ratios (Staerkjear and Menné, 1990; Bass et al., 1993; Das et al., 2008). The most frequent mechanisms of adverse reactions induced by metals are: a) corrosion, which is dependent on the presence of oxygen, chlorides, and non-noble metal alloys in the oral cavity, and b) the gradual and continuous release of ionic components from dental materials. Such ionic components are absorbed in the human body, either through the digestive system, oral mucosa, skin, or airways (Eliades and Athanasiou, 2002; Costa et al., 2007). The most common adverse reactions are caused by metal toxicity, sub-toxic reactions, hypersensitivity, and allergic contact dermatitis (Pedemonte et al., 2006). The carcinogenic effects of Ni have been demonstrated through exposure pathways such as ingestion, inhalation, and parenteral injection of $\mathrm{Ni}$ compounds (Kasprzak et al., 2003; Pedemonte et al., 2006). Therefore, because of its wide use in dentistry, it is important to investigate the genotoxic effects of topical odontological exposure to metal alloys that include Ni. The micronucleus (MN) test of exfoliated cells in epithelial tissue has been used to evaluate the genotoxic effects produced by low doses of carcinogenic substances, or mixtures, which are carcinogenic, to exposed human populations. The frequency of MN in human exfoliated cells can be used as an "endogenous dosimeter" in tissues that are specific targets of genotoxic carcinogens, where carcinomas can then develop (Martino-Roth et al., 2003). The MN assay is widely used today because it is practical, fast, economical, and measures irreversible damage at the nuclear chromatin level, offering many advantages over other assays used previously to measure DNA damage such as the comet test. Compared to the comet test, trials have shown that $\mathrm{MN}$ is more sensitive for detecting genotoxicity. Given this, the application of the MN test is thus considered useful for measuring genotoxic damage caused by odontological metal alloys. Through the analysis of buccal epithelial cells and urine samples, the objective of the current study was to determine the extent of Ni-induced DNA damage in 37 pediatric subjects with metal dental crowns.

\section{MATERIAL AND METHODS}

\section{Inclusion criteria}

We recruited 42 pediatric patients. The parents of each patient signed a letter of con- 
sent for participation in the study. All protocols used in the current study were approved by the Bioethics Committee at the Facultad de Medicina, Universidad Autónoma de Coahuila, Unidad Torreón. Participants were considered to meet inclusion criteria if they were eligible for treatment with dental preformed metal crowns. Patients included those with severely decayed teeth involving 2 or more tooth surfaces, interproximal contact loss, changes in mesiodistal and buccolingual dimensions, and mesial tipping of the first permanent molar; primary teeth that had been treated with pulpotomy or pulpectomy, structural defects such as enamel hypoplasia, hypocalcification, imperfect amelogenesis, or imperfect dentinogenesis that could not be restored properly with conventional techniques; retainers for the fabrication of space maintainers, and removable and fixed appliances used in preventive and interceptive orthodontics; and subjects with pretreatment of metal crowns, with no metal seals or fixed oral appliances and without previously diagnosed systemic diseases. Subjects were excluded if they presented piercings in the mouth, or reported carrying metal stents. In addition, patients were also excluded if sampling of oral epithelial cells and/or urine was taken \pm 1 day from the scheduled time points $(1,15$, and 45 days post-crown placement), or if they removed their metal crown for any reason during the 1 to 45 days of exposure.

\section{Determination of the alloy of the metal crown}

To determine the concentration of metal alloys, crown samples were evaluated using Atomic Absorption Spectroscopy on a Perkin-Elmer 5100 spectrophotometer (Perkin-Elmer, Norwalk, CT, USA).

\section{Collection and sample preparation}

Three samples were collected from oral mucosa cells according to a standard protocol previously described by Titenko-Holland et al. (1994). Initial samples were collected on the day that the metal crowns were inserted, which was considered the first day of Ni exposure (basal value). The second and third samples were obtained 15 and 45 days post-exposure. Urine samples were collected in a plastic container on days 1 (basal value), 15, and 45 following the placement of the dental crown; samples were collected midstream from the first urination of each collection day, and were refrigerated at $4^{\circ} \mathrm{C}$ until processing. Urine samples were prewashed with $10 \%$ nitric acid, rinsed with distilled water, and dried at room temperature.

\section{Measurement of urine Ni concentrations by inductively coupled plasma mass spectometry (ICP-MS)}

We used ICP-MS (Elan 6000 DRC II, Los Angeles, CA, USA) to measure the urine Ni concentration according to previously described methods (Fernández-Ruíz, 2003); concentrations are reported as $\mu \mathrm{g} \mathrm{Ni} / \mathrm{g}$ creatinine.

\section{MN assay}

After collecting and analyzing cheek cells, slides of buccal cells were prepared by dropping the washed cell suspension onto prewarmed slides $\left(37^{\circ} \mathrm{C}\right)$. Slides were then air-dried and fixed in $80 \%(\mathrm{v} / \mathrm{v})$ methanol at $0^{\circ} \mathrm{C}$ for $20 \mathrm{~min}$, and again allowed to dry at room tem- 
perature before being stained with Giemsa solution (Jalmek G0700-02, USA). Subsequently, $1 \mathrm{~mL}$ Giemsa solution was placed on each slide and was left to rest for $20 \mathrm{~min}$. Slides were then rinsed with deionized water, followed by tri-distilled water, and allowed to dry at room temperature. For preservation, slides were covered with a layer of resin [synthetic resin solution in $60 \%$ xylene (Jalmek SR175-12, USA)] and dried for 8 days. Each slide was observed at an amplification of 100X with a light microscope (Micromaster 640 EE7055); the number of normal, micronucleated, binucleated, and necrotic cells were determined. Cells exhibiting degenerative processes such as karyorrhexis, karyolysis, and pyknosis were considered as one group of necrotic cells. Binucleated and micronucleated cells were identified according to the characteristics described by Zalacaín et al. (2005), and apoptotic cells were identified according to those set by Holland et al. (2008). Duplicate slides were made for each patient and 500 cells were read per slide, totaling 1000 cells per patient sample.

\section{Statistical analysis}

The SAS 9.0 software package was used to calculate measures of central tendency and dispersion, and to conduct an analysis of variance (ANOVA, Kruskal-Wallis) in independent populations over time. Data analysis was performed by using the Statistical Analysis System software SAS, Version 9.0 (SAS Institute, Cary, NC, USA).

\section{RESULTS}

Statistical analysis was performed on 37 of the 42 patients originally selected for the study. Subjects included were between 4 and 11 years of age (mean $=6.26 \pm 1.79$ years). Of these, $62.16 \%$ were males and $37.84 \%$ were females; $87 \%$ of the males and $86 \%$ of the females were 8 years of age or younger. The sampled crowns were found to contain $70.85 \%$ iron $(\mathrm{Fe}), 19.28 \% \mathrm{Ni}$, and $9.62 \% \mathrm{Cr}$. Analysis of urine samples from the 3 time periods revealed that longer $\mathrm{Ni}$ exposure leads to significant increasing in $\mathrm{Ni}$ concentrations of $57 \%$ between 1 and 15 days $(\mathrm{P}<0.05)$ and $71 \%$ between 1 and 45 days of exposure $(\mathrm{P}<0.05)$. However, Ni concentrations observed at 15 and 45 days were not significantly different $(\mathrm{P}>0.05)$. Figure 1 shows mean urinary Ni concentrations for the 3 exposure times. The Ni concentration at day 1 was $2.12 \pm 1.23 \mu \mathrm{g} \mathrm{Ni} / \mathrm{g}$ creatinine. After 15 and 45 days of exposure, the Ni concentration had increased to $3.25 \pm 2.03$ and $3.86 \pm 2.96 \mu \mathrm{g} \mathrm{Ni} / \mathrm{g}$ creatinine.

Results of the MN assays showed a statistically significant increase in the frequency of micronucleated cells in samples collected after 45 days of exposure compared to those collected at day $1(\mathrm{P}<0.05)$. However, the frequencies of micronucleated cells were not significantly different between samples collected at 1 and 15 days, nor between 15 and 45 days of exposure $(\mathrm{P}>0.05$; Table 1). An increase in the number of necrotic cells, including those exhibiting karyorrhexis, karyolysis, and pyknosis, was also observed with increasing exposure. The numbers of necrotic cells observed in samples from each time point are shown in Figure 2. The frequencies of abnormalities per 1000 cells are shown in Table 2. The number of necrotic cells in males and females was not found to be significantly different at any of the 3 time points $(\mathrm{P}>0.05)$. However, a slight increase was observed at 15 days of exposure compared to day 1 (5.73 \pm 2.70 and $6.78 \pm 4.11$, respectively). The frequency of binucleated cells in males was significantly different between samples at day $1(2.17 \pm 2.69)$ and day $45(3.08 \pm 2.48 ; \mathrm{P}<$ $0.05)$. In girls, significant differences were observed between 15 and 45 days post-exposure ( $\mathrm{P}$ 
$<0.001)$. After partitioning by gender, a difference in the frequency of micronucleated cells was observed only in male samples collected at days 1 and $45(\mathrm{P}<0.05$; Table 2$)$.

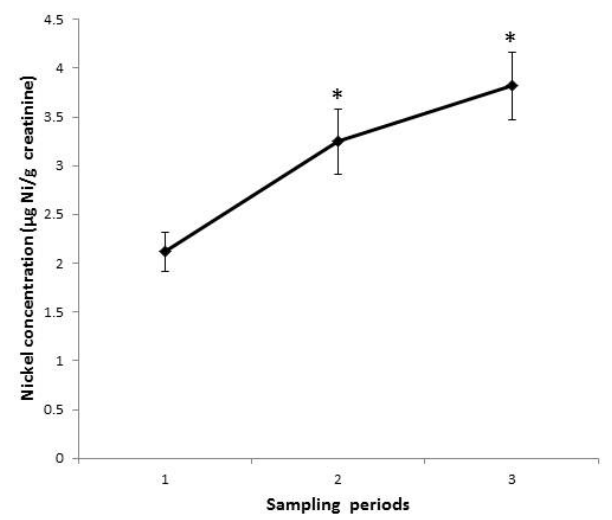

Figure 1. Concentration of urinary excretion of nickel $(\mathrm{Ni})$ in the three sampling periods of exposure [1 (basal value), 15 , and 45 days; means $\pm \mathrm{SE}$. Unit of measure: $\mu \mathrm{g} \mathrm{Ni} / \mathrm{g}$ creatinine $(* \mathrm{P}<0.05)$.

Table 1. Frequency of micronucleated, binucleated, and necrotic cells in the 3 sampling periods.

\begin{tabular}{lccr}
\hline Sample & & Frequency for every 1000 cells (means \pm SE) \\
\cline { 2 - 4 } & Micronucleated cells & Binucleated cells & Necrotic cells \\
\hline Basal (1 day) & $4.67 \pm 0.15^{\mathrm{b}}$ & $2.81 \pm 0.087^{\mathrm{a}}$ & $5.24 \pm 0.096^{\mathrm{b}}$ \\
15 days & $5.48 \pm 0.126^{\mathrm{a}}$ & $3.02 \pm 0.073^{\mathrm{a}}$ & $6.43 \pm 0.129^{\mathrm{a}}$ \\
45 days & $6.78 \pm 0.167^{\mathrm{a}}$ & $2.56 \pm 0.072^{\mathrm{a}}$ & $5.56 \pm 0.108^{\mathrm{b}}$
\end{tabular}

Similar letters in the column are statistically similar $\left(\mathrm{P} \geq \chi^{2}, \alpha=0.05\right)$.

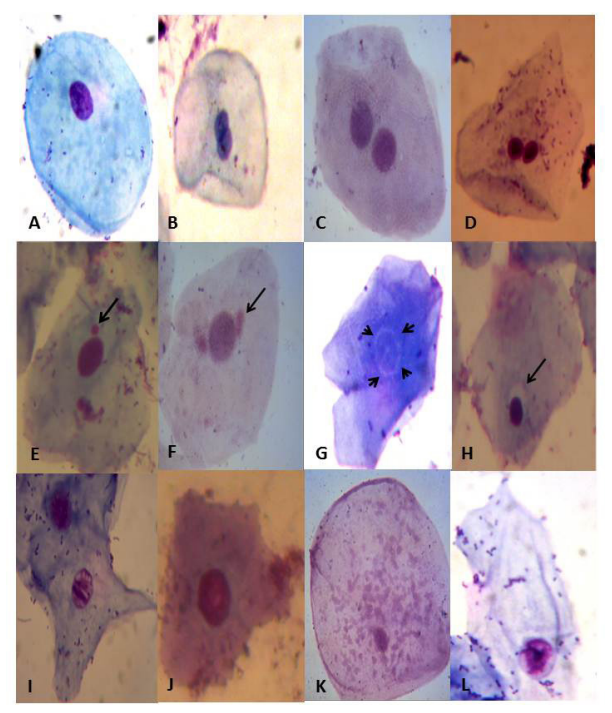

Figure 2. Epithelial cells of oral mucosa in degeneration processes: A. Normal cell. B. C. D. Binucleated cell. E. F. Cell with micronucleus. G. Cell in karyolysis. H. Cell in pyknosis. I. J. K. L. Cell in karyorrhexis. Giemsa stain, $100 X$. 
Table 2. Frequency per gender of micronucleated, binucleated, and necrotic cells in the 3 sampling periods.

\begin{tabular}{|c|c|c|c|c|c|c|}
\hline \multirow[b]{3}{*}{ Sample } & \multicolumn{6}{|c|}{ Frequency for every 1000 cells (means $\pm \mathrm{SE}$ ) } \\
\hline & \multicolumn{2}{|c|}{ Micronucleated cells } & \multicolumn{2}{|c|}{ Binucleated cells } & \multicolumn{2}{|c|}{ Necrotic cells } \\
\hline & Female & Male & Female & Male & Female & Male \\
\hline Basal (1 day) & $5.42 \pm 4.92^{\mathrm{a}}$ & $4.21 \pm 4.76^{\mathrm{a}}$ & $3.85 \pm 2.68^{\mathrm{a}}$ & $2.17 \pm 2.69^{\mathrm{a}}$ & $4.42 \pm 3.47^{\mathrm{a}}$ & $5.73 \pm 2.70^{\mathrm{a}}$ \\
\hline 15 days & $5.42 \pm 3.36^{\mathrm{a}}$ & $5.52 \pm 4.39^{\mathrm{ab}}$ & $3.71 \pm 2.46^{\mathrm{ab}}$ & $2.60 \pm 2.21^{\mathrm{a}}$ & $5.85 \pm 4.16^{\mathrm{a}}$ & $6.78 \pm 4.11^{\mathrm{a}}$ \\
\hline 45 days & $6.85 \pm 4.73^{\mathrm{a}}$ & $6.73 \pm 5.46^{\mathrm{b}}$ & $1.71 \pm 1.77^{\circ}$ & $3.08 \pm 2.48^{\mathrm{a}}$ & $6.57 \pm 3.43^{\mathrm{a}}$ & $4.95 \pm 3.37^{\mathrm{a}}$ \\
\hline
\end{tabular}

Similar letters in the column are statically similar $\left(\mathrm{P} \geq \chi^{2}, \alpha=0.05\right)$.

\section{DISCUSSION}

We observed that in the 37 participants the frequency of micronucleated cells increased linearly with the concentration of Ni excreted in the urine. The significant increase of $\mathrm{Ni}$ in the urine coincides with that reported by Grandjean et al. (1988), who observed higher concentrations after 28 days of occupational exposure to this metal. In other studies, similar results are reported in orthodontic apparatus users (Barret et al., 1993; Menezes et al., 2007; Petoumenou et al., 2009; Sahoo et al., 2011). Our data suggest that the MN assay is a suitable dosimeter for the assessment of topical exposure to metals such as $\mathrm{Ni}$ in vivo as we observed that both the number of cells with micronuclei as well as the urinary concentration of Ni were significantly increased at 45 days following the placement of Ni-based metal crowns. In 1997, Vijaya Bhaskar and Subba-Reddy (1997) reported a significant increase in the concentration of $\mathrm{Ni}$ and $\mathrm{Cr}$ ions in the saliva of metal crown users at 7 days after the placement of a single crown; however, the concentrations decreased to negligible levels after 28 days of crown placement. Due to this, it was expected that the count of micronucleated cells would peak at 15 days and damage would decrease after 45 days. However, in our study, we found evidence that $\mathrm{Ni}$ concentrations in urine increased with time. The increase of the frequency of micronucleated cells is partly due to the interaction of the metals in question. It is well known that the 3 metals are associated with the onset of cancer and genotoxic damage. Fe alloyed with $\mathrm{Ni}$ produces a protective effect to genotoxic damage according to Kasprzak et al. (2003). Thus, the fact that we observed an increased number of micronucleated cells at day 45 compared to day 15 is likely explained by a loss of ions.

Here, we present evidence that the count of cells with micronuclei is a sensitive method for determining genotoxic damage. Indeed, the alloy metal found in the crowns used in our study showed that, after $\mathrm{Fe}$, Ni was the second most abundant. Other studies have shown that metallic ions such as $\mathrm{Ni}$ and cobalt released from orthodontic appliances could induce DNA damage in oral mucosa cells and in mouse fibroblasts in vitro (Schmalz et al., 1998; al-Hiyasat et al., 2002; Faccioni et al., 2003). Therefore, we can say that there is evidence that exposure to metal crowns produces genotoxic damage 45 days after exposure. The proposed model allows us to conclude that there is DNA damage induced by metal ions; however, it cannot be said that this damage is exclusively due to the $\mathrm{Ni}$, as it is alloyed with steel $(\mathrm{Fe})$ and $\mathrm{Cr}$, both metals with known genotoxic effects. Ni was used as a biomarker of indirect control of the concentrations of metal ions absorbed and metabolized via the levels excreted in urine, since this metal is eliminated in the same form as when it is absorbed, Ni (II), without interacting with the metabolism (Danadevi et al., 2004; Lewinska et al., 2007). Population studies assessing the number of micronucleated cells in subjects with orthodontic devices have shown increases 
within 30 days after the placement of these devices. In this sense, it is important to note that no tests have been described that demonstrate the genotoxicity induced by orthodontic appliances. However, in future studies, it will be important to consider each metal individually, and compare which of the three releases more ions, for how long, and if its genotoxic effects vary in relation to purity or interactions with other metals. Longer patient follow-up periods, as well as the use of additional serum and urinary biomarkers could provide further insight as to whether genotoxic damage induced by metal crowns in buccal cells is permanent and can progress to cancer, and whether lowering the secretion levels of these metals will make the use of metal crowns safer. In conclusion, this study provides evidence of genotoxic damage caused by exposure to $\mathrm{Ni}$ in children with metal crowns.

\section{Conflicts of interest}

The authors declare no conflicts of interest.

\section{ACKNOWLEDGMENTS}

We thank Laboratorio de Metales of the MET-MEX Peñoles for carrying out the urine $\mathrm{Ni}$ analysis, and the 42 children and their parents who voluntarily consented to participate in the study. K.D. Moreal-de Luna and N.D. Betancourt-Martínez were supported by CONACyT scholarships \#298027 and \#18046, respectively.

\section{REFERENCES}

al-Hiyasat AS, Bashabsheh OM and Darmani H (2002). Elements released from dental casting alloys and their cytotoxic effects. Int. J. Prosthodont. 15: 473-478.

Amini F, Borzabadi FA, Jafari A and Rabbani M (2008). In vivo study of metal content of oral mucosa cells in patients with and without fixed orthodontic appliances. Orthod. Craniofac. Res. 11: 51-56.

Barrett RD, Bishara SE and Quinn JK (1993). Biodegradation of orthodontic appliances. Part I. Biodegradation of nickel and chromium in vitro. Am. J. Orthod. Dentofacial Orthop. 103: 8-14.

Bass JK, Fine H and Cisneros GJ (1993). Nickel hypersensitivity in the orthodontic patient. Am. J. Orthod. Dentofacial Orthop. 103: 280-285.

Costa MT, Lenza MA, Gosch CS, Costa I, et al. (2007). In vitro evaluation of corrosion and cytotoxicity of orthodontic brackets. J. Dent. Res. 86: 441-445.

Danadevi K, Rozati R, Banu BS and Grover P (2004). Genotoxic evaluation of welders occupationally exposed to chromium and nickel using the Comet and micronucleus assays. Mutagenesis 19: 35-41.

Das K, Bose S, Bandyopadhyay A, Karandikar B, et al. (2008). Surface coatings for improvement of bone cell materials and antimicrobial activities of Ti implants. J. Biomed. Mater. Res. B Appl. Biomater. 87: 455-460.

Eliades $\mathrm{T}$ and Athanasiou AE (2002). In vivo aging of orthodontic alloys: implications for corrosion potential, nickel release, and biocompatibility. Angle Orthod. 72: 222-237.

Faccioni F, Franceschetti P, Cerpelloni M and Fracasso ME (2003). In vivo study on metal release from fixed orthodontic appliances and DNA damage in oral mucosa cells. Am. J. Orthod. Dentofacial Orthop. 124: 687-693.

Fernández-Ruíz R (2003). La Técnica De Plasma-Masas (ICP-MS). Recuperado el 11 de Mayo de 2011. Available at [http://www.uam.es/personal_pas/txrf/icpms.html]. Accessed December 19, 2011.

Grandjean P, Andersen O and Nielsen GG (1988). Indicadores Biológicos para la Valoración de la Exposición Humana a Compuestos Químicos Industriales: Níquel. 1st edn. Diario Del Puerto De Valencia, S.L., Brussels, Luxembourg, 29-39.

Holland N, Bolognesi C, Kirsch-Volders M, Bonassi S, et al. (2008). The micronucleus assay in human buccal cells as a tool for biomonitoring DNA damage: the HUMN project perspective on current status and knowledge gaps. Mutat. Res. 659: 93-108. 
Kasprzak KS, Sunderman FW Jr and Salnikow K (2003). Nickel carcinogenesis. Mutat. Res. 533: 67-97.

Lewinska D, Palus J, Stepnik M, Dziubaltowska E, et al. (2007). Micronucleus frequency in peripheral blood lymphocytes and buccal mucosa cells of copper smelter workers, with special regard to arsenic exposure. Int. Arch. Occup. Environ. Health 80: 371-380.

Liu IH, Lee TM, Chang CY and Liu CK (2007). Effect of load deflection on corrosion behavior of NiTi wire. J. Dent. Res. 86: 539-543.

Martino-Roth MG, Viégas J and Roth DM (2003). Occupational genotoxicity risk evaluation through the comet assay and the micronucleus test. Genet. Mol. Res. 2: 410-417.

Menezes LM, Quintão CA and Bolognese AM (2007). Urinary excretion levels of nickel in orthodontic patients. Am. J. Orthod. Dentofacial Orthop. 131: 635-638.

Pedemonte S, Chimenos E and López J (2006). El níquel en odontología. DENTUM Rev. Mat. Dentales 6: 26-34.

Petoumenou E, Arndt M, Keilig L, Reimann S, et al. (2009). Nickel concentration in the saliva of patients with nickeltitanium orthodontic appliances. Am. J. Orthod. Dentofacial Orthop. 135: 59-65.

Sahoo N, Kailasam V, Padmanabhan S and Chitharanjan AB (2011). In-vivo evaluation of salivary nickel and chromium levels in conventional and self-ligating brackets. Am. J. Orthod. Dentofacial Orthop. 140: 340-345.

Schmalz G, Langer H and Schweikl H (1998). Cytotoxicity of dental alloy extracts and corresponding metal salt solutions. J. Dent. Res. 77: 1772-1778.

Shin JS, Oh KT and Hwang CJ (2003). In vitro surface corrosion of stainless steel and NiTi orthodontic appliances. Aust. Orthod. J. 19: 13-18.

Staerkjaer L and Menné T (1990). Nickel allergy and orthodontic treatment. Eur. J. Orthod. 12: 284-289.

Titenko-Holland N, Moore LE and Smith MT (1994). Measurement and characterization of micronuclei in exfoliated human cells by fluorescence in situ hybridization with a centromeric probe. Mutat. Res. 312: 39-50.

Vijaya Bhaskar B and Subba-Reddy V (1997). Biodegradation of nickel and chromium from stainless steel crowns and space maintainers - an in vitro study. Ann. Dent. Univ. Malaya 4: 17-21.

Westphalen GH, Menezes LM, Prá D, Garcia GG, et al. (2008). In vivo determination of genotoxicity induced by metals from orthodontic appliances using micronucleus and comet assays. Genet. Mol. Res. 7: 1259-1266.

Zalacaín M, Sierrasesúmaga L and Patiño A (2005). El ensayo micronúcleos como medida de inestabilidad genética inducida por agentes genotóxicos. An. Sist. Sanit. Navar. 28: 227-236. 